\title{
Recovery Compressive Strength Aluminum Fiber Light Weight Concrete after Burning With Variation of Water Curing Time
}

\author{
Antonius Mediyanto ${ }^{1}$, Bambang Santosa ${ }^{2}$, Edy Purwanto ${ }^{3}$, Jb.Irawan S.W. ${ }^{4}$ \\ \{mediyantoantonius@gmail.com ${ }^{1}$, bb_santosa@yahoo.co.id ${ }^{2}$, edysip88@gmail.com ${ }^{3}$ \} \\ Department of Civil Engineering, Universitas Sebelas Maret, Jl. Ir. Sutami 36A 575125, Indonesia ${ }^{123}$, \\ Environmental Science Program, Universitas Sebelas Maret, Jl. Ir. Sutami 36A 575125, Indonesia ${ }^{4}$
}

\begin{abstract}
The research concerns on strenght of light weight concrete with aluminum fiber as micro-reinforcement by enviromental load especially burning and water curing. The purpose of this study was to determine the minimum time of water curing to obtain a minimum compressive strength of $100.00 \%$ recovery. In this research cylindrical concrete of $150 \mathrm{~mm}$ dia $300 \mathrm{~mm}$ high for compressive test. Fiber volume fraction are $0,75 \%$ of concrete. Aluminum fiber with aspect ratio 50, cement type I, sand, alwa, water, and viscocrete are used. Testing are based on SK SNI M-14-1989-F [1]. The result shows that the minimum time to recovery of lightweight concrete compressive strength with water curing is 42 days, while for aluminum fiber lightweight concrete to recovery compressive strength is 28 days. Water curing can self healing light weight concrete and aluminum fiber light weight concrete after burning.
\end{abstract}

Keyword: water curing, light weight concrete, burning.

\section{Background}

An improvement of lightweight aggregate performance is needed in order to compensate for the performance of the cement paste but remain light. The use of fiber as an added ingredient in lightweight concrete is a solution to the phenomenon that light concrete is more brittle than normal concrete [2] that aluminum fiber has been able to increase the compressive strength, cylinder split strength of, MOR by improving the quality of the matrix due to the bridging, dowel action, and composite action processes. Improve the performance of lightweight concrete beams in the form of increased bending capacity, ductility, and shear capacity.

The subject of this research is oriented specifically on the possibility of improving the quality of lightweight concrete material by studying the phenomenon of temperature insulation, fiber bridging, and its composite action due to the addition of fiber, especially in pre-burn, postburning conditions, and after water curing with various intensities for 28 days, 42 days and 56 days to obtain minimum time for $100.00 \%$ minimum recovery.

Given 28 days of water curing treatment on post-burn aluminum fiber metakaolin lightweight concrete [3], can increase the average compressive strength, average elastic modulus, average cylinder split strength, and average modulus of rupture; $38.46 \%, 44.47 \%$, $85.12 \%$, and $25.21 \%$ respectively. This means that water curing efforts help the recovery of ICCSET 2018, October 25-26, Kudus, Indonesia

Copyright (C) 2018 EAI

DOI 10.4108/eai.24-10-2018.2280573 
tubermorite $(3 \mathrm{CaO} 2 \mathrm{SiO} 23 \mathrm{H} 2 \mathrm{O})$ as the element that determines the strength of the concrete needs to be studied more in depth.

The purpose of this study was to determine the minimum time of water curing to obtain a minimum compressive strength of $100.00 \%$ recovery.

\section{Literature review}

Wetting post-burn concrete with water, restoring strength by building $\beta 3 \mathrm{CaO} 2 \mathrm{SiO} 23 \mathrm{H} 2 \mathrm{O}$ in its crystal [4]. The structure of $3 \mathrm{CaO} 2 \mathrm{SiO} 23 \mathrm{H} 2 \mathrm{O}$ is amorph which consists of $\mathrm{CaO}, \mathrm{SiO}$, and $\mathrm{H} 2 \mathrm{O}$ with the ratio of $\mathrm{CaO}$ and $\mathrm{SiO} 2$ is 1.5 and the amount of $\mathrm{H} 2 \mathrm{O}$ is highly dependent of the surrounding conditions; from 1 dry condition, up to 4 in saturation condition. The crystal of water released by the combustion temperature may still be able to return to its position if there is water entering around the $3 \mathrm{CaO} 2 \mathrm{SiO} 23 \mathrm{H} 2 \mathrm{O}$ crystal. The presence of this crystalline water greatly affects the density of $3 \mathrm{CaO} 2 \mathrm{SiO} 23 \mathrm{H} 2 \mathrm{O}$, which ultimately affects the strength of its $3 \mathrm{CaO} 2 \mathrm{SiO} 23 \mathrm{H} 2 \mathrm{O}$.

The residual of the lightweight concrete stresses in $\%$ of the initial value due to the increase in temperature respectively; $200^{\circ} \mathrm{C}, 300^{\circ} \mathrm{C}, 400^{\circ} \mathrm{C}, 500^{\circ} \mathrm{C}, 600^{\circ} \mathrm{C}, 650^{\circ} \mathrm{C}, 700^{\circ} \mathrm{C}, 800^{\circ} \mathrm{C}$, and $850^{\circ} \mathrm{C}$ are respectively; $95 \%, 92 \%, 90 \%, 85 \%, 90 \%, 95 \%, 75 \%, 60 \%$ and $50 \%$.

The residual strength of the structures which has cooled down after it burns will depend on the highest temperatures during the fires, the mixtures used and the loading conditions during fires. In addition, due to the characteristics of heat transfer, only the temperature at the outer part increases dramatically while the inside of the concrete temperature depends on the depth of the outermost shell [4]. Example research with $30 \times 40 \times 1500 \mathrm{~cm} 3$ column subjected to heating up to $1000 \mathrm{o} \mathrm{C}$, in the surface of concrete where temperature reached 835 o C. However, the temperature inside the concrete is only $150 \mathrm{o} \mathrm{C}$ for $7.5 \mathrm{~cm}$ depth and $100 \mathrm{o} \mathrm{C}$ for $10 \mathrm{~cm}$ depth, although steel reinforcement is $2.5 \mathrm{~cm}$ depth high enough temperature $650 \mathrm{o} \mathrm{C}$. This shows that the outside temperature of combustion can be much different from the temperature inside the concrete. This also makes this research very interesting, especially changes in the nature and strength of steel reinforcement in lightweight concrete with a variety of added materials in it.

Thermal stresses are caused by a non-uniform temperature distribution through the structure/element or by thermal expansion of an externally restrained section. These stresses can lead to a "brittle fracture and delamination buckling caused by compressive biaxial stresses parallel to the heated surface" [5].

The use of fiber in reinforced concrete can increase energy absorption, ductility, control cracks, and improve deformation properties [6]. The weakness of the properties of concrete, that is brittle, are practically incapable of withstanding tensile stress and bending moments can be improved by adding local fibers made of pieces of wire to a concrete mortar. It also proved that the rate of improvement obtained by using local fiber is not inferior to the results reported abroad using the original steel fiber [7]. 


\section{Research methods}

The materials used are water, cement type I, sand, coarse aggregate from roof tile fragments, and viscocrete. The equipment used are a set of scales and mixing of concrete, oven, cone Abram to measure slump, water bath for concrete treatment, furnace, wet gunny sack, and Compressing Testing Machine.

The basic material experiments are tested, including the test of mud content, screen analysis, specific gravity, absorption, and organic content in the sand. Coarse aggregate from roof tile fragments; abrasion test, sieve analysis, specific gravity, absorption, and mud content were performed. While cement and aluminum will be used data properties from the manufacturer.

The calculation of lightweight concrete mix will be used mix design based on data obtained from base material test with compressive strength ( $f^{\prime}$ c) $20 \mathrm{MPa}$ with medium slump. The addition of aluminum fiber is $0.75 \%$ from the volume of concrete with a size of $2 \mathrm{~mm} \times 50 \mathrm{~mm}$.

The test specimens are cylindrical diameter $150 \mathrm{~mm}$ height $300 \mathrm{~mm} ; 30$ pieces for compressive strength test. The test samples were subsequently treated (curing) by immersion for 7 days and treated in an open and humid room until the test age of 28 days. Subsequently, the specimen is partially tested and partially burned at $500^{\circ} \mathrm{C}$. This temperature is proposed assuming that the melting point of aluminum is $660^{\circ} \mathrm{C}$ (Callister [8]).

Some of the burned samples will be treated with variation water curing after the combustion process is complete, and the sample is tested at 28 days, 42 days and 56 days from the curing process. Testing of research material, making of specimen, concrete weighing test, lightweight concrete compressive strength test, and elasticity modulus test are conducted in Civil Engineering Materials Laboratory of UNS. Combustion is done at Bayat Klaten Ceramics Lab.

\section{Research results and discussion}

The sand used is sand tested based on the ASTM standard with a mud content of $2.3 \%$. The gradation table with a fineness modulus of sand of 2.55 . The specific gravity in saturated surface dry conditions is 2.50 [9].

Coarse aggregate used in this study is the result of roof tile fragments. A mud content of is $0.5 \%$, abrasion is $47 \%$, fineness modulus is 5.66 , the specific gravity in saturated surface dry conditions is 2.10 .

The aluminum fiber can improve the tensile strength of the concrete as it has a maximum tensile strength of $100 \mathrm{MPa}$ and an $11 \%$ elongation. The aluminum fibers used in this study are small pieces measuring $2 \mathrm{~mm} \times 50 \mathrm{~mm}$ in average.

The material requirement for $1 \mathrm{~m} 3$ of concrete is: $400.00 \mathrm{~kg}$ of cement, $634.90 \mathrm{~kg}$ of sand, $644.10 \mathrm{~kg}$ of roof tile fragments, 160.00 liters of water, $15.75 \mathrm{~kg}$ of aluminum fiber, and $4.00 \mathrm{~kg}$ of viscocrete. The compressive strength is calculated from the load divided by the crosssectional area. The compressive strength test can be seen as in Figure 1. 


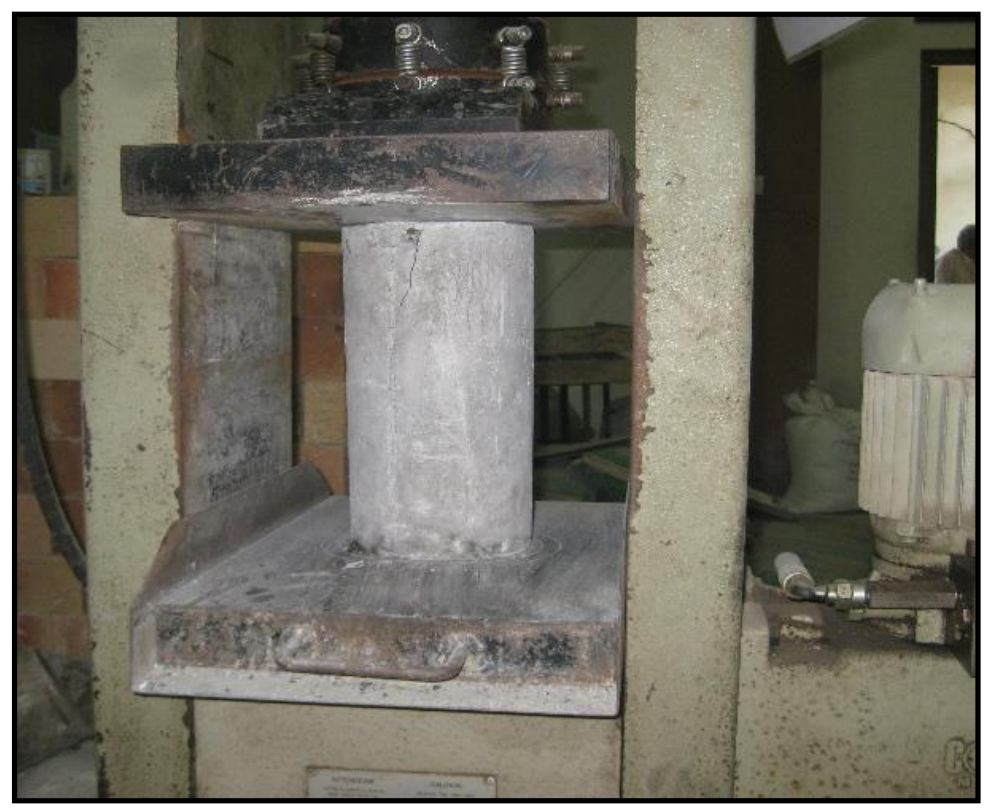

Fig.1. Set the compressive strength test.

The result of average compressive strength analysis in this research can be seen as in Figure 2 and is as follows:

For lightweight concrete the average compressive strength is:

a. Before Burning: $20.37 \mathrm{MPa}$

b. Burning $500^{\circ} \mathrm{C}: 19.05 \mathrm{MPa}$

c. Burning $500^{\circ} \mathrm{C}+$ Curing 28 days: $19.24 \mathrm{MPa}$

d. Burning $500^{\circ} \mathrm{C}+$ Curing 42 days: $21.31 \mathrm{MPa}$

e. Burning $500^{\circ} \mathrm{C}+$ Curing 56 days: $24.71 \mathrm{MPa}$

For aluminum fiber lightweight-concrete the average strength value is:

a. Before Burning: $23.76 \mathrm{MPa}$

b. Burning $500^{\circ} \mathrm{C}: 21.88 \mathrm{MPa}$

c. Burning $500^{\circ} \mathrm{C}+$ Curing 28 days: $25.08 \mathrm{MPa}$

d. Burning $500^{\circ} \mathrm{C}+$ Curing 42 days: $25.46 \mathrm{MPa}$

e. Burning $500^{\circ} \mathrm{C}+$ Curing 56 days: $26.03 \mathrm{MPa}$ 


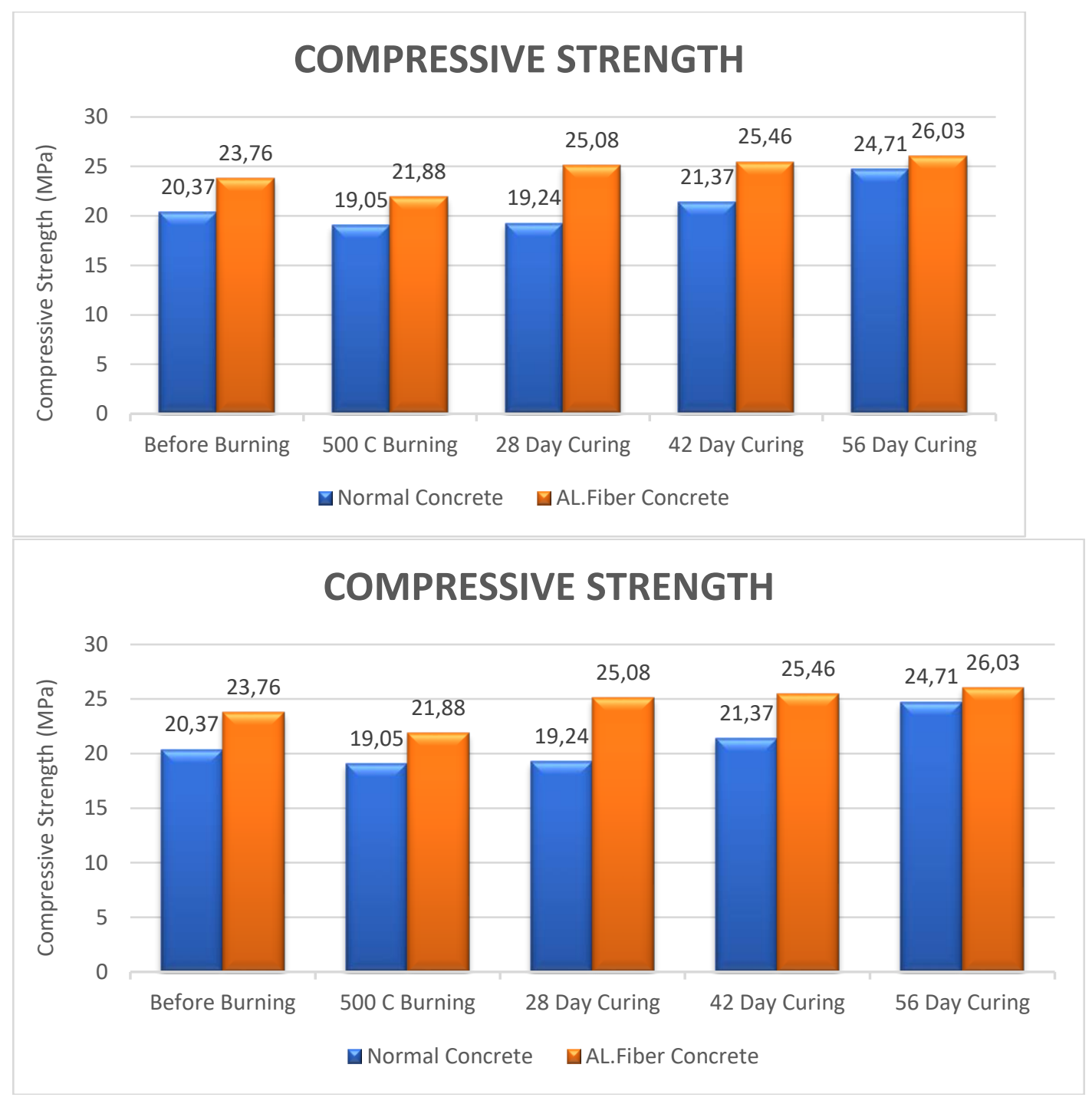

Fig 2. Compressive strength vs water curing time.

In this study the increasing self-recovery of average compressive strength on water curing 28 days, 42 days, and 56 days after combustion were 94.45\%, 104.61\%, and $121.31 \%$ respectively for lightweight concrete, whereas for aluminum fiber lightweight concrete the value of increasing self-recovery of average compressive strength were 105.56\%, 107.16\%, 109.55\% respectively.

The compressive strength recovery of lightweight concrete is $104.61 \%$ on water curing of 42 days, whereas a compressive strength recovery of aluminum fiber lightweight concrete is $105.56 \%$ at 28 days water curing. 
The process of water curing after the concrete is burned causes the water to absorb into the pores of the concrete and reacts with $2 \mathrm{CaOSiO}$ and $3 \mathrm{CaOSiO} 3$ compounds on cement granules yet to react as well as $\alpha 3 \mathrm{CaO} 2 \mathrm{SiO}_{3} \mathrm{H}_{2} \mathrm{O}$ compounds in the concrete due to combustion temperature, the reaction product of the compound being $\mathrm{CSH}$, and $\beta 3 \mathrm{CaO} 2 \mathrm{SiO}_{2} 3 \mathrm{H}_{2} \mathrm{O}$, able to restore the strength of concrete as before burning [3]. An additional hydration will fill the pore space left behind of vaporized pore water, increasing overall $3 \mathrm{CaO} 2 \mathrm{SiO} 23 \mathrm{H} 2 \mathrm{O}$ density. $\beta 3 \mathrm{CaO} 2 \mathrm{SiO} 23 \mathrm{H} 2 \mathrm{O}$ formed by increasing the amount of $\mathrm{H} 2 \mathrm{O}$ in the $3 \mathrm{CaO} 2 \mathrm{SiO} 23 \mathrm{H} 2 \mathrm{O}$ crystal will return the density and strength of its $3 \mathrm{CaO} 2 \mathrm{SiO} 23 \mathrm{H} 2 \mathrm{O}$.

The $3 \mathrm{CaO} 2 \mathrm{SiO} 23 \mathrm{H} 2 \mathrm{O}$ model before burning can be seen as shown in Figure 3 below. The $\mathrm{H} 2 \mathrm{O}$ attached to $\mathrm{SiO}_{2}$ in the combustion process will lose, resulting in decreased $3 \mathrm{CaO} 2 \mathrm{SiO}_{2} 3 \mathrm{H}_{2} \mathrm{O}$ density. The $3 \mathrm{CaO} 2 \mathrm{SiO}_{2} 3 \mathrm{H}_{2} \mathrm{O}$ model after combustion can be seen as in Figure 4 below.

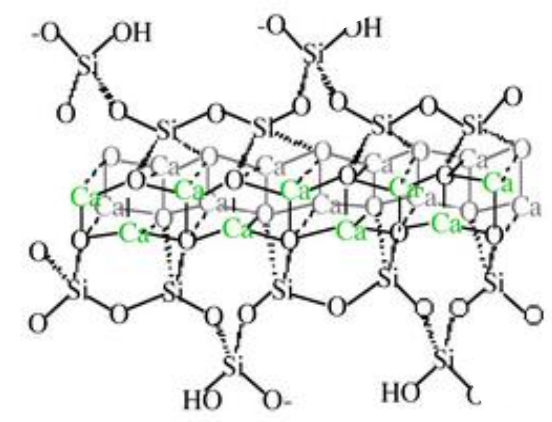

Fig. 3. The $3 \mathrm{CaO} 2 \mathrm{SiO}_{2} 3 \mathrm{H}_{2} \mathrm{O}$ model before burning.

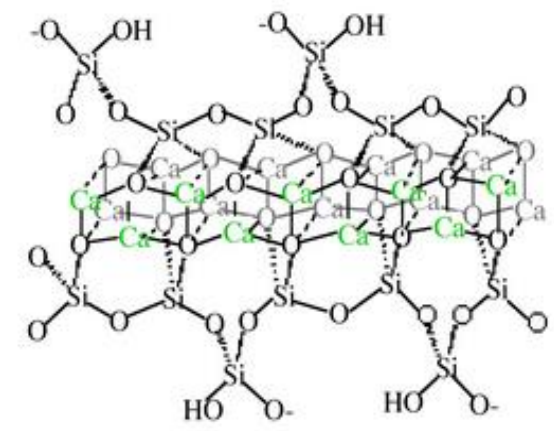

Fig. 4. The $3 \mathrm{CaO}_{2} \mathrm{SiO}_{2} \mathrm{H}_{2} \mathrm{O}$ model after burning. 
After treatment, the water permeates, enters and binds to the silicate again so that the $3 \mathrm{CaO} 2 \mathrm{SiO} 23 \mathrm{H} 2 \mathrm{O}$ density increases. The $3 \mathrm{CaO} 2 \mathrm{SiO} 23 \mathrm{H} 2 \mathrm{O}$ model after treatment with water as in Figure 5.

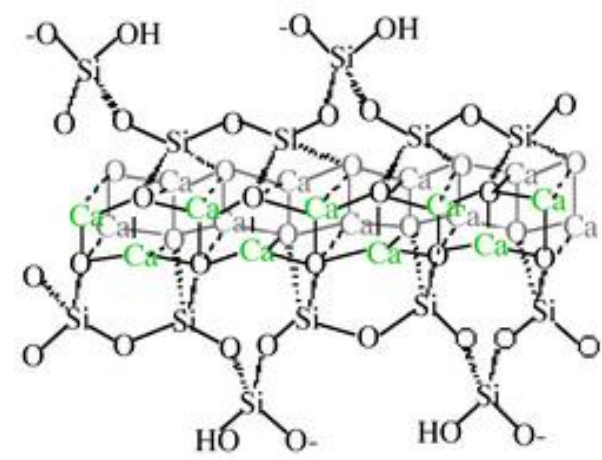

Fig. 5. The $3 \mathrm{CaO} 2 \mathrm{SiO}_{2} 3 \mathrm{H}_{2} \mathrm{O}$ model after water curing.

\section{Conclusion}

From the discussion of the results of the study can be concluded: The minimum time to recovery of lightweight concrete compressive strength with water curing is 42 days after combustion, while for aluminum fiber lightweight concrete to recovery compressive strength is 28 days.

\section{References}

[1] Anonymous and SNI 03 - 2847 - 2002 (SK SNI M-14-1989-F), "Procedures for calculation of concrete structures for buildings." pp. 03-2847, 2002.

[2] A. Mediyanto, S. Sangaji, Sudarmoko, and A. Triwiyono, "Study of mechanical properties and capacity of structural elements of lightweight aluminum fibrous concrete," Sebelas Maret University, 2004.

[3] A. Mediyanto, E. Safitri, and S. Purnomo, "The predicted model the capacity of lightweightmethacaolin-aluminum fiber-reinforced concrete of fire concrete column," 2011.

[4] A. Partowiyatmo and Sudarmadi, "Strength Recovery of Fire Concrete," in The 7th International Conference on Quality in Research (QIR), 2004, p. 6.

[5] R. Jansson, "Fire Spalling of Concrete," Doctoral Thesis in Concrete Structure, Sweden, 2013.

[6] R. . Zollo, "Fiber Reinforced Concrete: an overview after 30 years of development," Cemen Concr. Compos., vol. 19, pp. 107-122, 1997.

[7] B. Suhendro, "The Effect of Partial Fiber Usage on Behavior and Capacity of Reinforced Beam," in Material Mechanics to Increase the Potential of Local Materials, 1992.

[8] W. D. Callister, Materials Science \& Engineering. John Wiley \& Sons, Inc, 1997.

[9] A. D. E119-, "Standard Methods of Fire Tests of Building and Construction Materials," vol. 04.07, 1983. 